\title{
Changes in land use and physiological transitions of a Juniperus thurifera forest: from decline to recovery
}

\author{
Daniel Montesinos and Javier Fabado
}

\begin{abstract}
Forest decline is frequently associated with infection; however, infections habitually affect trees that have been previously debilitated by environmental stress. Nevertheless, the causes and physiology of noninfectious forest decline are not well known. Some Juniperus thurifera L. forests presented severe (noninfectious) declines, with defoliations over $50 \%$. The goal of this study was to determine the causes and characterize the physiology of this noninfectious decline, and we hypothesized that it could be related to environmental stress from increasing interspecific competition resulting from land abandonment. We randomly assigned 60 trees to either a control group or one of two competition-release treatments, i.e., vegetation clearing or soil ploughing. We characterized the physiological state of the trees both before treatment application and 14 months after treatment application. The J. thurifera trees that were declining experienced significantly lower soil nutrient and water availability, which resulted in lower leaf nutrient concentrations, lower photosynthetic rates, higher water stress, and arrested growth and reproduction. We confirmed that competition release increased nutrient availability and acquisition, reduced water deficit, improved photosynthetic rates, and abruptly stopped defoliation. Competition plays an increasingly critical role in forest conservation, particularly with the reported increase in the number of species colonizing previously unfeasible habitats due to global change and the absence of traditional activities that used to buffer competition.
\end{abstract}

Key words: forest management, forest decline, global change, Juniperus thurifera, land abandonment.

Résumé : Le dépérissement des forêts est souvent associé à des agents biotiques; cependant, les agents biotiques infectent habituellement les arbres déjà affaiblis par un stress environnemental. Malgré tout, les causes et la physiologie des dépérissements qui ne sont pas associés à des agents biotiques sont peu connues. Certaines forêts de Juniperus thurifera L. ont subi des dépérissements sévères d'origine abiotique qui ont causé plus de 50 \% de défoliation. Nous avons cherché à déterminer les causes et caractériser la physiologie de ce dépérissement d'origine abiotique et nous avons émis l'hypothèse qu'il pourrait être relié à un stress environnemental provoqué par l'augmentation de la compétition interspécifique à la suite de l'abandon des terres. Nous avons aléatoirement assigné 60 arbres à un groupe témoin ou à l'un ou l'autre des deux traitements visant à éliminer la compétition : le défrichage et le labourage. Nous avons caractérisé l'état physiologique des arbres avant et 14 mois après l'application des traitements. Les arbres qui dépérissaient ont souffert d'une disponibilité en eau et en nutriments du sol significativement réduite entraînant une plus faible concentration de nutriments dans les feuilles, un taux de photosynthèse plus bas, un stress hydrique plus prononcé ainsi que l'arrêt de la croissance et de la reproduction. Nous confirmons que l'élimination de la compétition a accru la disponibilité et l'acquisition des nutriments, réduit le déficit hydrique, amélioré le taux de photosynthèse et brusquement arrêté la défoliation. La compétition joue un rôle de plus en plus important dans la conservation de la forêt, particulièrement avec l'augmentation rapportée du nombre d'espèces qui colonisent des habitats jusque-là impraticables à cause du changement global et en l'absence d'activités traditionnelles qui avaient l'habitude de réguler la compétition. [Traduit par la Rédaction]

Mots-clés : aménagement forestier, dépérissement de la forêt, changement global, Juniperus thurifera, abandon des terres.

\section{Introduction}

Forest decline is frequently associated with infection (Franklin et al. 1987; McGraw et al. 1990); however, pathogens are normally the executioners, the newcomers to a list of pre-existing factors that have been wearying the trees during long stretches (Boddy and Rayner 1983; Jurskis 2005; Galiano et al. 2012). However, forest decline is usually preceded by some form of abiotic stress that subsequently intensifies the importance of competition, ultimately leading to higher vulnerability to infection and disease. Consequently, forest decline is usually related to chronic stress and often influenced by human management (Jurskis 2005). Numerous studies characterize different physiological aspects of tree decline, but such studies most often focus on trees already affected by diseases or wounds (Boddy and Rayner 1983). As a result, the physiology of declining forests unaffected by plague or disease has been insufficiently studied.

Low-intensity arable systems in which farmers preserved trees for shelter, wood, food, and forage maintained pseudo-steppes, which were once common across Europe (Bignal and McCracken 2000; McNeely and Schroth 2006). The abandonment of lowintensity agriculture and the progressive reduction in traditional livestock herding across Europe (Rozas et al. 2008; DeSoto et al. 2010 ) is increasing the pressure exerted by competitor species on numerous forests (Walther 2003; Petit et al. 2005; Hampe 2011; Olano et al. 2012). Changes in land use, combined with an increase

Received 4 November 2014. Accepted 26 February 2015.

D. Montesinos. Centro de Ecologia Funcional - Universidade de Coimbra, Calçada Martim de Freitas, $3000-456$ Coimbra, Portugal; Centro de Investigaciones sobre Desertificación - CIDE (CSIC-UV-GV), Carretera Montcada — Náquera, Km. 4.5, 46113 Montcada, Spain.

J. Fabado. Jardí Botànic de la Universitat de València, C/ Quart, 80, 46008 València, Spain.

Corresponding author: Daniel Montesinos (e-mail: danimontesinos@gmail.com). 
in temperatures or a reduction in precipitation as predicted due to global change (Intergovernmental Panel on Climate Change (IPCC) 2001; Petit et al. 2005; Schröter et al. 2005), are likely to synergistically increase environmental stress and are expected to change the forest structure and to reduce productivity (Gimeno et al. 2012). However, to date, these stressors have not been directly linked to specific cases of forest decline and severe defoliation.

Juniperus thurifera L. (Spanish juniper) trees occupied large areas of southern Europe, forming steppe-like forests during the Tertiary period. Nowadays, the species is relegated to disjunct populations in areas with poor soils, long and cold winters, and warm and dry summers (Terrab et al. 2008) in a compromise between high environmental stress (Montesinos et al. 2010) and interspecific competition (Costa Tenorio et al. 1997; Olano et al. 2012). These low-density forests have been traditionally used for seasonal, low-intensity cereal-crop farming and livestock herding (Costa Tenorio et al. 1997). Large areas of J. thurifera forests in Alpuente, Spain, presented severe degrees of defoliation with no signs of disease since at least 1998 (García Post et al. 2006; D. Montesinos, personal observation, April 2008). A preliminary study indicated that traditional farming could have had a positive impact on juniper forest conservation via increased nutrient availability and leaf production (García Post et al. 2006). This study aims to characterize the physiological mechanisms of juniper decline and to experimentally recreate the effects of traditional herding and farming by, respectively, removing vegetation (clearing) or simulating traditional ploughing techniques (ploughing) $10 \mathrm{~m}$ around the affected trees, while also studying a group of control trees. Particularly, we aimed to answer the following specific questions. (i) What are the physiological determinants of relictual forest decline? (ii) What are the physiological mechanisms involved in forest recovery after competition release? (iii) Is increased competition derived from land use changes responsible for defoliation and decline of these relict forests?

\section{Materials and methods}

\section{Study species}

Juniperus thurifera trees occur in disjunct populations scattered across the mountains of the western Mediterranean Basin (Gauquelin et al. 2002; Terrab et al. 2008). Juniper forests are classified as priority habitats for conservation by the European Union (Directive 92/43/EEC, EUNIS 9560, http://ec.europa.eu/environment/ nature/legislation/habitatsdirective/index_en.htm, accessed 13 April 2015) and form low-density pure stands or mixed open forests with Quercus ilex L., Quercus faginea Lam., Pinus nigra J.F. Arnold, Pinus sylvestris L., and Pinus pinaster Aiton. Trees are 5-10 $\mathrm{m}$ high $(20 \mathrm{~m}$ in exceptional cases) and often live for centuries (Bertaudière et al. 1999). Cones take 22 months to develop and ripen and contain, on average, 3.5 (range, 1-7) seeds (Montesinos et al. 2010). Seedling recruitment is severely limited by drought and nutrient availability, which can be partially alleviated by sex-biased self-facilitation (Montesinos et al. 2007). Juniperus thurifera is a mast-seeding species (Montesinos et al. 2012a). Although anthropogenic pressure is a serious problem for J. thurifera forests in northern Africa (Bertaudière et al. 2001; Gauquelin et al. 2002), regeneration in Europe is usually nonproblematic and is mainly limited by abiotic environmental factors such as nutrient availability and water stress (Montesinos et al. $2007,2012 b)$. Global change has been found to be already limiting to tree-ring growth in the most xeric populations as a result of increasing aridity (DeSoto et al. 2012).

\section{Study site}

Study site is located at an elevation of $1165 \mathrm{~m}$ near the town of Alpuente, Valencia, Spain (approximately $39^{\circ} 57^{\prime} 25.48^{\prime \prime} \mathrm{N}, 1^{\circ} 00^{\prime} 01.99^{\prime \prime} \mathrm{W}$ ). Climate is classified as cold, semi-arid Mediterranean. Mean annual precipitation is $472 \mathrm{~mm}$, and mean annual temperature is
$12{ }^{\circ} \mathrm{C}$. Soils are calcareous on top of consolidated material, with calcium carbonate on all horizons and an organic horizon that is always less than $20 \mathrm{~cm}$ thick (Rubio Delgado et al. 1996). The area still presents some cereal crops intercalated with low-density $J$. thurifera forests, although frequent abandoned terraces and other farming structures prove that these crops were far more common in the past. Juniperus thurifera appears accompanied by Quercus ilex ssp. ballota (Desf.) Samp. and several pine species (P. nigra, P. sylvestris, P. pinaster, and Pinus halepensis Mill.) of uncertain origin, with an important presence of shrubs and herbs that is mainly composed of individuals of Rosmarinus officinalis L., Juniperus oxycedrus L., Juniperus phoenicea L., Thymus vulgaris L., Lavandula latifolia Medik., Genista scorpius (L.) DC., Santolina chamaecyparissus subsp. squarrosa (DC.) Nyman, and Euphorbia nicaeensis All.

\section{Experimental design}

Sixty trees were randomly selected across the population of Alpuente, where most individuals presented intense defoliation and a lack of reproduction. Trees were individually marked and assigned to one of three experimental groups of 20 individuals each: control, cleared, and ploughed. To facilitate the application of treatments at field sites, while including a representative number of individuals and environmental conditions within the study population, we grouped 10 individuals of each experimental group into two subareas that included 30 individuals each (10 for each treatment), were separated from each other by $200 \mathrm{~m}$, and had areas of 0.5 and 0.9 ha. Control trees were left as they were. For cleared treatments, all herbaceous and shrubby vegetation was removed in a $10 \mathrm{~m}$ radius around each tree, and for the ploughed treatment, vegetation was removed and soil was ploughed to a depth of $50 \mathrm{~cm}$ to at least a $10 \mathrm{~m}$ radius from each tree. For both clearing and ploughing, removed vegetation was shredded into small pieces and left on site. Treatments were applied during July 2010. In addition to that initial treatment, ploughing was repeated two more times in April and November 2011. At the beginning of the experiment, we morphologically characterized the 60 marked trees, which had a mean diameter at breast height $(1.5 \mathrm{~m})$ of $0.596 \pm 4.89 \mathrm{~cm}$ (mean \pm standard error (SE)) (coefficient of variation $(\mathrm{CV})=63 \%$ ) and mean tree height of $3.933 \pm 0.019 \mathrm{~cm}(\mathrm{CV}=35 \%)$. Mean tree biomass, as derived from height and crown diameter measurements (Zaoui et al. 2000), was $154.40 \pm 31.06 \mathrm{~kg}(\mathrm{CV}=20 \%)$. Initial defoliation (see methodology below) was $55.68 \% \pm 2.64 \%(\mathrm{CV}=36 \%)$. We did not find significant differences in biomass (general linear model: $F_{[2,57]}=0.43$; $p=0.652)$ or for initial defoliation $\left(F_{[1,2]}=2.79 ; p=0.070\right)$ among individuals assigned to the three different experimental groups. After the application of the different treatments, we made a number of measurements on all marked trees, including measurements of soil chemistry, leaf chemistry, and changes in defoliation.

- Soil chemistry. In September 2011, we took three samples at different points below each individual with a cylinder that was $10 \mathrm{~cm}$ in diameter and $15 \mathrm{~cm}$ in depth. All three samples from below each individual were mixed together and analyzed by Agrolab Analítica S.L. (Navarra, Spain) to determine the relative concentration in essential nutrients, particularly organic matter $(\mathrm{OM})$ by potentiometry, nitrogen $(\mathrm{N})$ by the Kjeldahl method (Lang 1958), phosphorous (P) by the Olsen method (Olsen 1954) and colorimetry at $880 \mathrm{~nm}$, and potassium (K) by spectrophotometry of atomic absorption.

- Leaf chemistry. In September 2011, we took the terminal tip $(15 \mathrm{~cm})$ at $1.5 \mathrm{~m}$ height of three different branches on three different random orientations from each individual. The three samples from each tree were combined and analyzed to determine its relative concentration on essential nutrients, particularly total $\mathrm{N}$ by the Kjeldahl method and $\mathrm{P}$ and $\mathrm{K}$ both by spectrophotometry of induced plasma (ICP-OES). 
- Changes in defoliation. We estimated the defoliation before the initiation of the treatments (September 2009) and before a final defoliation (June 2011), based on the standardized methodology for the estimation of forest defoliation developed by the United Nations and the European Network for Forest Damages (ICP Forests 2010), on which the official European regulations are based (EC regulation 1696/87; http://eur-lex.europa.eu/legalcontent/EN/TXT/?uri=CELEX:31987R1696, accessed 13 April 2015). The methodology is based on visual estimations of defoliation of a target tree in 5\% steps compared with a reference tree representing the typical crown morphology and age of trees in the vicinity, to which a $0 \%$ defoliation value is attributed (see detailed methodology at http://icp-forests.net/page/icp-forests-manual, accessed 13 April 2015).

Branch photosynthetic rate $\left(A, \mu \mathrm{mol} \mathrm{CO} \cdot \cdot \mathrm{m}^{-2} \cdot \mathrm{s}^{-1}\right)$ was estimated with a portable photosynthetic system (LCi, ADC BioScientific Ltd., Herts, UK). Because leaves were tiny and scale-like, physiological measurements were taken from shoots, for which surface areas were estimated following allometric transformations previously developed for this same species (Montesinos et al. 2012b). Photosynthetic rates $(A)$ were measured on one shoot per individual at breast height and random orientation at noon on three different clear days in July, August, and September of 2011. Water potential was estimated following the same procedure at noon on the same days with a Scholander chamber (SKPM 1400 series, Skye Instruments Ltd., Powys, UK).

Finally, reproductive efforts were estimated by counting the number of male or female cones (hereafter, flowers) and fleshy berries (hereafter, fruits) present on the final $20 \mathrm{~cm}$ of 10 branches randomly chosen around the crown of each of the 60 individuals during the 3 years of study (2009-2011). Flowering was estimated during January, and fruiting was estimated during October.

\section{Statistical analyses}

Statistical analyses were performed with IBM-SPSS 19 (Norusis 2002), and data were tested for homoscedasticity. Soil and leaf chemistry, as well as reduction in defoliation rates, were analyzed by a general linear model with treatment as a fixed factor and Tukey's $b$ post-hoc tests. Differences in $A$, water potential $(\Psi)$, flowering, and fruiting were assessed by linear mixed models, with those variables as dependent variables, shoot biomass as the covariable, treatment as a fixed factor, and time as a repeated measurement, by using a first-order autoregressive covariance structure.

\section{Results}

Consistently, for all variables, competition release by shrub clearing or ploughing similarly improved tree conditions. Juniperus thurifera trees presented an initial defoliation of $55 \%$ in the studied area; after 21 months, trees experiencing either of the two treatments had reduced defoliation to an average of only $40 \%\left(F_{[1,2]}=\right.$ 7.50; $p=0.001$ ), a total reduction of $27 \%$ in the defoliation rate (there were no differences between clearing and ploughing, $p=0.828$; Fig. 1). Treatments improved tree water potential by $10 \%$ overall $\left(\mathrm{F}_{[2,72]}=4.45 ; p=0.015\right)$, with no difference between clearing and ploughing ( $p=0.472$; Fig. 1 ; Supplementary Fig. S1 $\left.{ }^{1}\right)$. Photosynthesis net rate improved similarly, with treated individuals having $20 \%$ higher photosynthetic rates than controls overall $\left(F_{[2,61]}=3.72 ; p=0.030\right)$, with no differences between clearing and ploughing ( $p=0.832$; Fig. 1 ; Supplementary Fig. $\left.S 1^{1}\right)$. Soil nutrient analysis also showed that both clearing and ploughing significantly increased nutrient availability in terms of OM $(80 \%$ increment; $\left.F_{[2,57]}=8.79 ; p<0.001\right)$, $\mathrm{N}$ concentration $(35 \%$ increment; $\left.F_{[2,57]}=7.52 ; p=0.001\right), P$ concentration $\left(153 \%\right.$ increment; $F_{[2,57]}=$
Fig. 1. Reduction in defoliation (\%), net photosynthesis rate $\left(\mu \mathrm{mol} \mathrm{CO}{ }_{2} \cdot \mathrm{m}^{-2} \cdot \mathrm{s}^{-1}\right)$, and shoot water potential (MPa) of trees from each of the three groups: control, cleared, and ploughed (mean \pm SE). Different letters indicate statistically significant differences among groups.

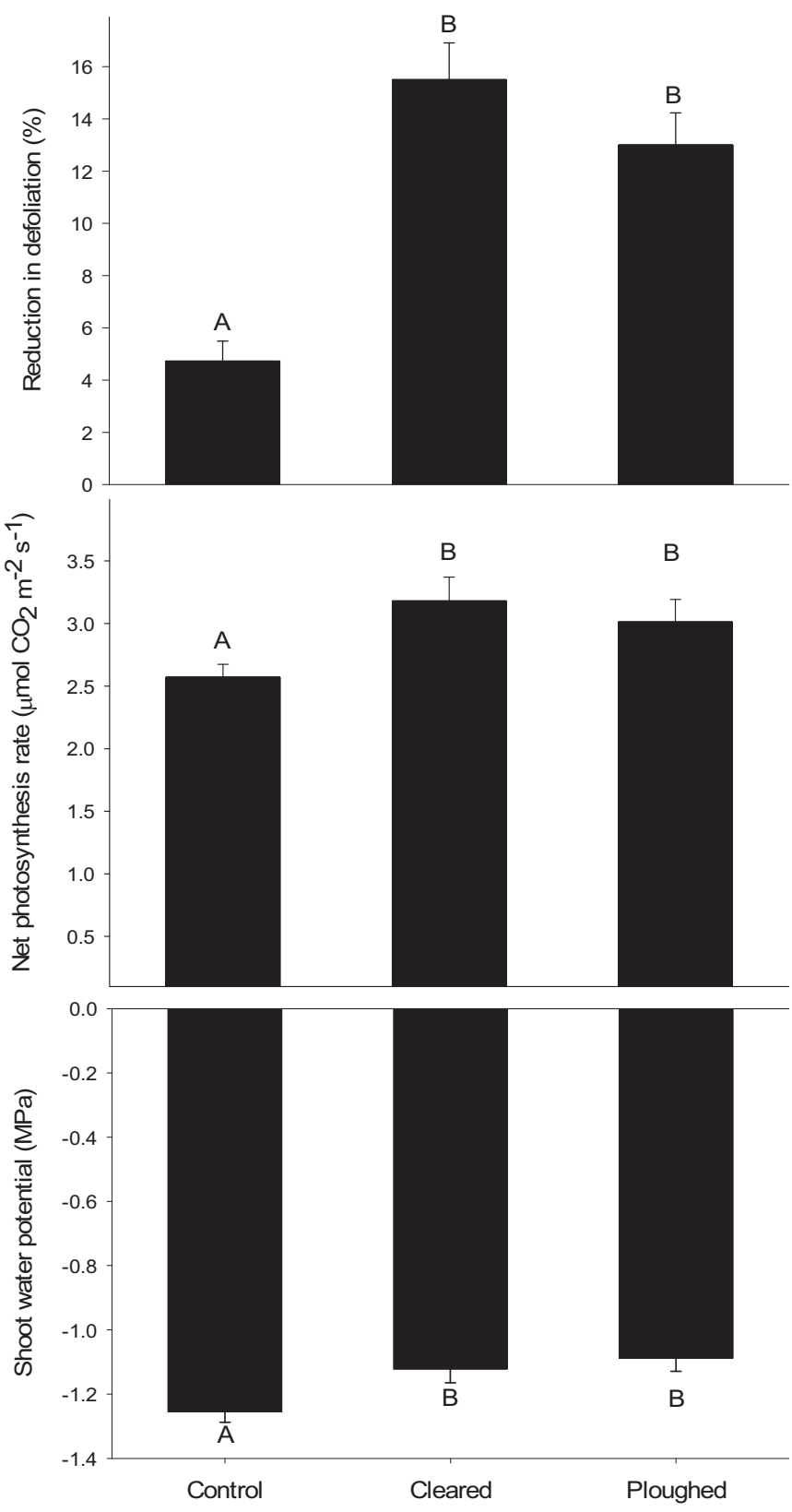

17.75; $p<0.001)$, and $\mathrm{K}$ concentration $\left(243 \%\right.$ increment; $F_{[2,57]}=$ 20.43; $p<0.001$ ). Post-hoc tests showed that clearing and ploughing presented similar values between them but were higher than controls $(p<0.05)$, except for P concentration, which was significantly higher in cleared soils than in controls $(116 \%$ increment; $p<0.05)$ but significantly lower than in ploughed soils $(190 \%$ increment compared with controls; $p<0.05$; Fig. 2). Leaf chemical analyses closely mirrored soil chemical analyses, although reflecting different assimilation rates for each nutrient. Treatments increased branch nutrient concentration for both $\mathrm{N}$ (35\% higher concentration than controls; $\left.F_{[2,57]}=42.04 ; p<0.001\right)$ and $\mathrm{P}\left(20 \%\right.$ increase; $F_{[2,57]}=5.20$;

${ }^{1}$ Supplementary Fig. S1 is available with the article through the journal Web site at http://nrcresearchpress.com/doi/suppl/10.1139/cjfr-2014-0468. 
Fig. 2. Nutrient ( $K$, potassium; $P$, phosphorus; $N$, nitrogen) and organic matter $(\mathrm{OM})$ concentrations on soil collected under trees from each of the three groups: control, cleared, and ploughed (mean \pm SE). Different letters indicate statistically significant differences among groups.

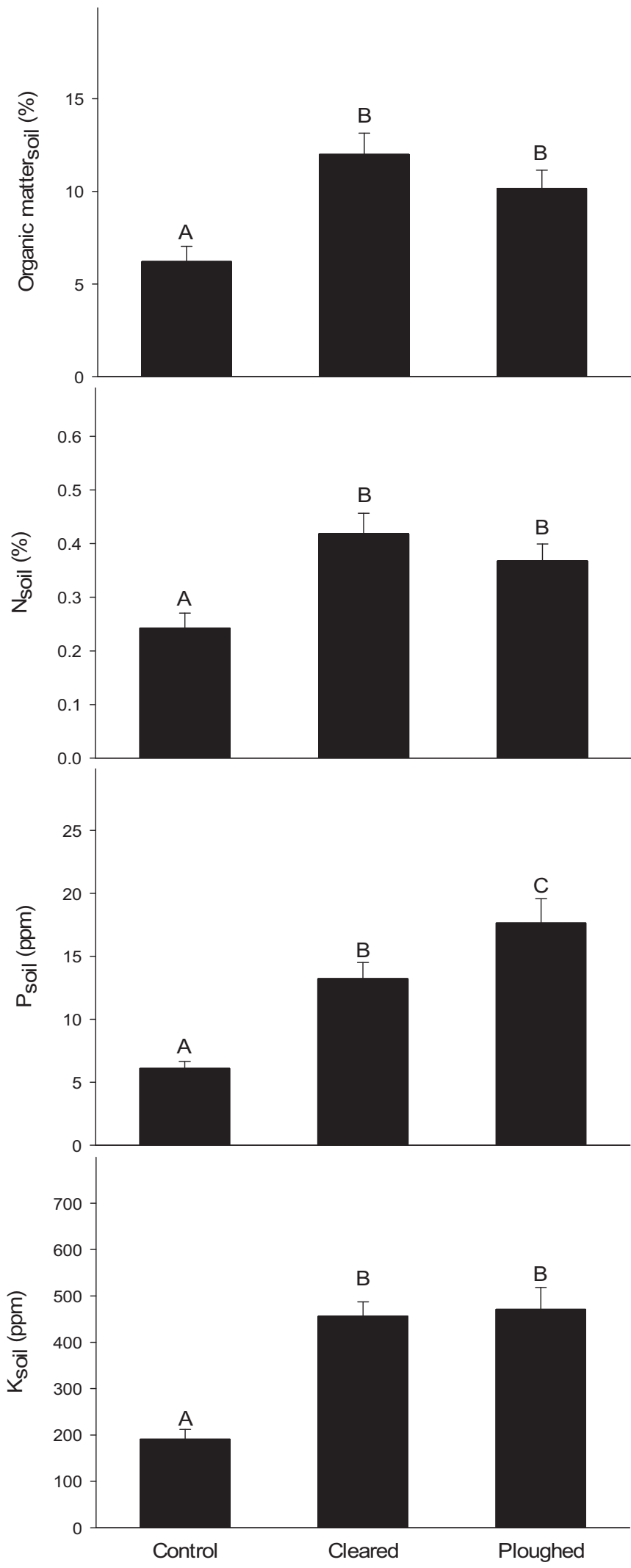

$p=0.008$ ), although no differences among treatments were found for $\mathrm{K}\left(\mathrm{F}_{[2,57]}=0.91 ; p=0.409\right)$. Post-hoc tests showed that both clearing and ploughing significantly increased $\mathrm{N}$ concentration over the concentration present on control individuals $(p<0.05)$. $P$ concentration presented a similar pattern in soils, although for branch $\mathrm{P}$, differences were not as important, finding statistically significant differences $(p<0.05)$ between control and ploughing (26\% increase over controls), whereas the individuals on the cleared sites ( $13 \%$ increase over controls) presented intermediate values that were not significantly different from either of the other two groups (Fig. 3). Finally, no significant differences were found among treatments for flowering rates $(8.02 \pm 3.08$ flowers per branch; $\left.F_{[2,60]}=0.90 ; p=0.412\right)$ or for fruiting rates $(1.41 \pm$ 0.69 fruits per branch; $F_{[2,57]}=1.47 ; p=0.238$ ).

\section{Discussion}

Experimental simulation of traditional land management resulted in the recovery of decaying J. thurifera trees. Physiological characterization of the transitions between decline and recovery showed that, compared with treated individuals, declining trees experienced significantly lower soil nutrient and water availability, which resulted in lower leaf nutrient concentrations, lower photosynthetic rates, higher water stress, and arrested reproduction and growth. Simulation of traditional farming consistently reversed all these processes, rapidly increasing nutrient availability, which directly translated into increased nutrient acquisition, reduced water deficit, improved photosynthetic rates, and dramatic reductions in defoliation (i.e., branch growth). After experimental release from competition, defoliation decreased from $55 \%$ to $40 \%$, a clear indicator of the general improvement $(27 \%)$ in the health condition of the treated individuals. This improvement could be related to the general increase in soil nutrient content, reflecting the addition of $\mathrm{OM}$ via shredded vegetation, the liberation and mobilization of soil nutrients due to degradation of the roots of former competitors, and the development of denser crowns (Prescott 2002; but see Munger et al. (2003)). This resulted in important increases in branch nutrient concentration and in improved physiological values overall. The physiology of defoliation on declining forests has been studied mainly as a consequence of either disease or herbivory (Franklin et al. 1987; McGraw et al. 1990), but water scarcity also plays a critical role on crown condition and forest decline, particularly in Mediterranean environments (Galiano et al. 2012). In our study, water potential of treated individuals improved by $10 \%$, reflecting the escape from competition for water with shrubs. Consequently, with such a significant improvement in both water availability and nutrient concentration, treated individuals increased their photosynthetic rates by $20 \%$, which explains why treated trees produced more branches and reduced defoliation so quickly, in line with previous studies of changes in tree-ring growth after forest clearings (Rozas et al. 2008) and with preliminary studies in J. thurifera (García Post et al. 2006). Reproduction is one of the first detectable traits of stress and decline (García et al. 1999; Hensen et al. 2005). The lack of improvement in reproduction in the short term was anticipated for J. thurifera, a masting species with cycles longer than 5 years, requiring long periods to reflect changes in the environment at the reproductive level (Montesinos et al. 2012a, 2012b).

Our study experimentally confirmed the importance of lowintensity traditional activities for the conservation of relict populations by releasing individuals from competition. Human activities are key to controlling the competitive displacement of many relict forests (Grabherr et al. 1994; Gottfried et al. 1999; Alward et al. 1999; Saxe et al. 2001; Walther 2003; Olano et al. 2012). Herding is one of those traditional activities, and J. thurifera, as most junipers, has a high tolerance to herbivory, as sheep and goats prefer other more palatable species if they are available; recent studies indicate that a generalized reduction in livestock 
Fig. 3. Branch nutrient (K, potassium; $P$, phosphorus; $N$, nitrogen) concentrations (\%) in trees from each of the three groups: control, cleared, and ploughed (mean \pm SE). Different letters indicate statistically significant differences among groups.
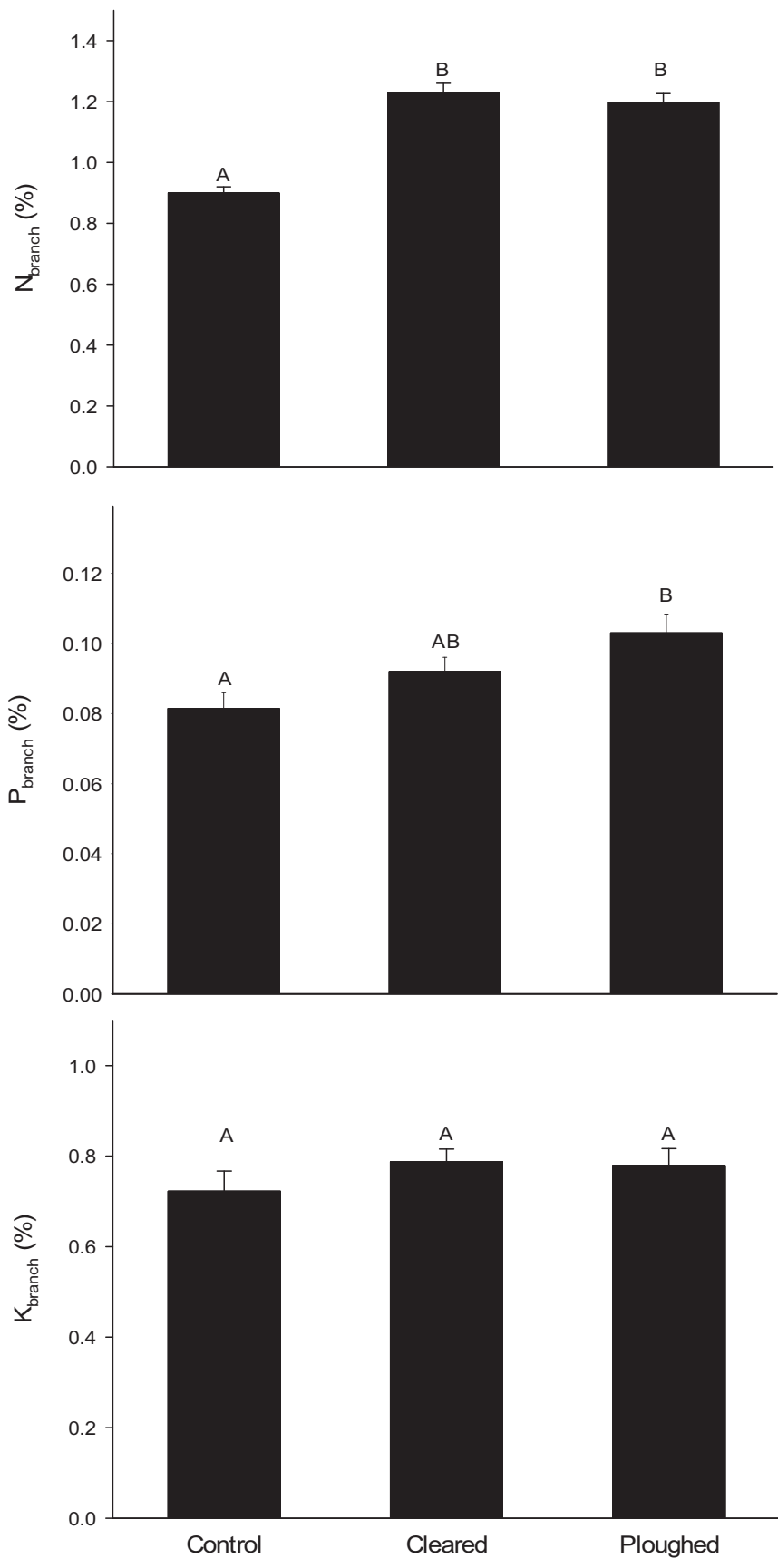

pressure in the Iberian Peninsula is causing a competitive displacement of these junipers by other species that used to be controlled by traditional herding (Montesinos et al. 2007; Rozas et al. 2008). Consequently, many pure J. thurifera forests are slowly transforming into mixed forests with a significant presence of Q. ilex and P. sylvestris due to competitive displacement (DeSoto et al. 2010; Olano et al. 2012). This pattern could be reinforced by climate change, which is expanding the distributions of potential competitor species (Grabherr et al. 1994; Gottfried et al. 1999; Alward et al. 1999; Walther 2003) and is already diminishing $J$. thurifera tree growth in the most xeric populations (DeSoto et al. 2012). Data from this study confirm this trend and suggest that traditional farming and herding facilitated the conservation of $J$. thurifera forests in areas in which they could have been competitively displaced otherwise. It is necessary to remark, however, that an excessive anthropogenic pressure could also have a negative impact on J. thurifera forests (DeSoto et al. 2010; Gimeno et al. 2011), as appears to happen on the southern Moroccan populations (Bertaudière et al. 2001; Gauquelin et al. 2002).

Historically, the distribution of J. thurifera has been considered to be limited by competition with species with higher growth rates and faster life cycles (Ruiz de la Torre and Ceballos 1971; Loehle 1998), and in fact, it is able to colonize recently abandoned lands due to lowered competition in these areas (Gimeno et al. 2011). It has been suggested that long-living species could buffer the effects of changes in climate (Bennet et al. 1991). However, our data indicate that competition can result in rapid declines, which could become irreversible after only a few decades as a consequence of halts on reproduction and regeneration (Montesinos et al. 2009) in a species known to be highly sensitive to microhabitat conditions for recruitment (Montesinos et al. 2007; Gimeno et al. 2012). The widely distributed J. communis is known to be similarly sensitive to competition and water limitation, particularly at the extremes of their latitudinal distribution, where their populations occur scattered in relict mountain areas (García et al. 2000; Verdú et al. 2004; García and Zamora 2003). Such species would potentially benefit from maintaining traditional farming and herding or from alternative competition-release treatments in those populations limited by climate or competition (Hampe 2011).

Robust models studying the dynamics of several Iberian forest species, including $J$. thurifera, predict that global change will strongly increase the impact of competition in the following years and recommend competition alleviation to manage vulnerable species (Gómez-Aparicio et al. 2011). Other models also indicate that competition release could have a significant positive impact on the conservation of European forests vulnerable to climate change induced drought (Guillemot et al. 2014). Our data contribute to the experimental validation of those models, confirming that selective interventions by bush cleaning are effective management techniques, particularly in the face of changes in complex physiological interactions as a result of global change.

\section{Acknowledgements}

We especially thank Patricio García-Fayos and Miguel Verdú for their advice and for granting us the use of the LCi and Scholander chamber. We also thank María Verdú and Esther Lorente, from Vaersa, for their help on the field sites and Lucía DeSoto for suggestions and corrections. This work was supported by Conselleria de Infraestructura, Territori i Medi Ambient, Generalitat Valenciana, Spain.

\section{References}

-Alward, R.D., Detling, J.K., and Milchunas, D.G. 1999. Grassland vegetation changes and nocturnal global warming. Science, 283(5399): 229-231. doi:10. 1126/science.283.5399.229.

Bennet, K.D., Willis, K.J., and Tzedakis, P.C. 1991. Quaternary refugia of north European trees. J. Biogeogr. 18: 103-115. doi:10.2307/2845248.

Bertaudière, V., Montès, N., Gauquelin, T., Edouard, J.L. 1999. Dendroécologie du genévrier thurifère (Juniperus thurifera L.): exemple de la thuriféraie de la Montagne de Rié (Pyrénées, France). Annals of Forest Science, 56: 685-697. doi:10.1051/forest:19990806. Available from www.afs-journal.org/articles/ forest/abs/1999/08/AFS_0003-4312_1999_56_8_ART0006/AFS_00034312_1999_56_8_ART0006.html.

Bertaudière, V., Montès, N., Badri, W., and Gauquelin, T. 2001. The multistemmed structure of Juniperus thurifera: adaptive advantage in a severe environment? C. R. Acad. Sci. Ser. III, 324(7): 627-634.

Bignal, E.M., and McCracken, D.I. 2000. The nature conservation value of European traditional farming systems. Environ. Rev. 8(3): 149-171. doi:10.1139/ a00-009.

Boddy, L., and Rayner, A. 1983. Origins of decay in living deciduous trees: the role of moisture content and a re-appraisal of the expanded concept of tree decay. New Phytol. 94: 623-641. doi:10.1111/j.1469-8137.1983.tb04871.x. 
Costa Tenorio, M., Morla Juaristi, C., Sainz Ollero, H., Blanco, E., Casado, M.A., Escribano, R., García, M., Génova, M., Gómez, A., Gómez, F., Moreno, J.C., and Regato, P. 1997. Los bosques ibéricos. Una interpretación geobotánica. Planeta, Barcelona.

DeSoto, L., Olano, J.M., Rozas, V., and De la Cruz, M. 2010. Release of Juniperus thurifera woodlands from herbivore-mediated arrested succession in Spain. Appl. Veg. Sci. 13: 15-25. doi:10.1111/j.1654-109X.2009.01045.x.

DeSoto, L., Camarero, J.J., Olano, J.M., and Rozas, V. 2012. Geographically structured and temporally unstable growth responses of Juniperus thurifera to recent climate variability in the Iberian Peninsula. Eur. J. For. Res. 131(4): 905-917. doi:10.1007/s10342-011-0564-7.

Franklin, J.F., Shugart, H.H., and Harmon, M.E. 1987. Death as an ecological process. The causes, consequences, and variability of tree mortality. BioScience, 37(8): 550-556.

Galiano, L., Martínez-Vilalta, J., Sabaté, S., and Lloret, F. 2012. Determinants of drought effects on crown condition and their relationship with depletion of carbon reserves in a Mediterranean holm oak forest. Tree Physiol. 32: 478489. doi:10.1093/treephys/tps025.

García, D., and Zamora, R. 2003. Persistence, multiple demographic strategies and conservation in long-lived Mediterranean plants. J. Veg. Sci. 14(6): 921926. doi:10.1111/j.1654-1103.2003.tb02227.x.

García, D., Zamora, R., Hódar, J.A., and Gómez, J.M. 1999. Age structure of Juniperus communis L. in the Iberian peninsula: conservation of remnant populations in Mediterranean mountains. Biol. Conserv. 87(2): 215-220. doi:10. 1016/S0006-3207(98)00059-7.

García, D., Zamora, R., Gomez, J.M., Jordano, P., and Hodar, J.A. 2000. Geographical variation in seed production, predation and abortion in Juniperus communis throughout its range in Europe. J. Ecol. 88(3): 435-446. doi:10.1046/j.13652745.2000.00459.x

García Post, R., González López, E., and Sanchís Duato, E. 2006. Recuperación de sabinas albares (Juniperus thurifera L.) en la localidad de Alpuente (Valencia). Foresta, 37(4): 22-27.

Gauquelin, T., Bertaudière-Montes, V., Badri, W., and Montès, N. 2002. Sex ratio and sexual dimorphism in mountain dioecious thuriferous juniper (Juniperus thurifera L., Cupressaceae). Bot. J. Linn. Soc. 138(2): 237-244. doi:10.1046/j.10958339.2002.138002237.x.

- Gimeno, T.E., Pías, B., Martínez-Fernández, J., Quiroga, D.L., Escudero, A., and Valladares, F. 2011. The decreased competition in expanding versus mature juniper woodlands is counteracted by adverse climatic effects on growth. Eur. J. For. Res. 131(4): 977-987. doi:10.1007/s10342-011-0569-2.

-Gimeno, T.E., Escudero, A., Delgado, A., and Valladares, F. 2012. Previous land use alters the effect of climate change and facilitation on expanding woodlands of Spanish juniper. Ecosystems, 15(4): 564-579. doi:10.1007/s10021-0129529-z.

- Gómez-Aparicio, L., García-Valdés, R., Ruíz-Benito, P., and Zavala, M.A. 2011. Disentangling the relative importance of climate, size and competition on tree growth in Iberian forests: implications for forest management under global change. Glob. Chang. Biol. 17: 2400-2414. doi:10.1111/j.1365-2486.2011. 02421.x.

Gottfried, M., Pauli, H., Reiter, K., and Grabherr, G. 1999. A fine-scaled predictive model for changes in species distribution patterns of high mountain plants induced by climate warming. Divers. Distrib. 5: 241-251. doi:10.1046/j.14724642.1999.00058.x.

Grabherr, G., Gottfried, M., and Pauli, H. 1994. Climate effects on mountain plants. Nature, 369(6480): 448. doi:10.1038/369448a0.

Guillemot, J., Delpierre, N., Vallet, P., Franc, C., Martin-StPaul, N.K., Soudani, K., Nicolas, M., Badeau, V., and Dufrêne, E. 2014. Assessing the effects of management on forest growth across France: insights from a new functionalstructural model. Ann. Bot. 114(4): 779-793. doi:10.1093/aob/mcu059.

-Hampe, A. 2011. Climatic relicts: past, present, future. Annu. Rev. Ecol. Evol. Syst. 42(1): 313-333. doi:10.1146/annurev-ecolsys-102710-145015.

Hensen, I., Ronnenberg, K., and Wesche, K. 2005. Lack of sexual reproduction within mountain steppe populations of the clonal shrub Juniperus sabina L. in semi-arid southern Mongolia. J. Arid Environ. 63: 390-405. doi:10.1016/j. jaridenv.2005.03.014.

ICP Forests. 2010. Manual on methods and criteria for harmonized sampling, assessment, monitoring and analysis of the effects of air pollution on forests. UNECE, ICP Forests, Hamburg, Germany. Available from http:/ icp-forests.net/ [accessed 13 April 2015].

Intergovernmental Panel on Climate Change (IPCC). 2001. Climate change 2001: the scientific basis. Cambridge University Press, Cambridge, UK.

Jurskis, V. 2005. Eucalypt decline in Australia, and a general concept of tree decline and dieback. For. Ecol. Manage. 215(1-3): 1-20. doi:10.1016/j.foreco. 2005.04.026.

Lang, C.A. 1958. Simple microdetermination of Kjeldahl nitrogen in biological materials. Anal. Chem. 30(10): 1692-1694. doi:10.1021/ac60142a038.

Loehle, C. 1998. Height growth rate tradeoffs determine northern and southern range limits for trees. J. Biogeogr. 25: 735-742. doi:10.1046/j.1365-2699.1998. 2540735.x.

McGraw, J.B., Gottschalk, K.W., Vavrek, M.C. and Chester, A.L. 1990. Interactive effects of resource availabilities and defoliation on photosynthesis, growth, and mortality of red oak seedlings. Tree Physiol. 7(1-2-3-4): 247-254. doi:10. 1093/treephys/7.1-2-3-4.247.

McNeely, J.A., and Schroth, G. 2006. Agroforestry and biodiversity conservation traditional practices, present dynamics, and lessons for the future. Biodivers. Conserv. 15(2): 549-554. doi:10.1007/s10531-005-2087-3.

Montesinos, D., Verdú, M., and García-Fayos, P. 2007. Moms are better nurses than dads: sex biased self-facilitation in a dioecious juniper tree. J. Veg. Sci. 18: 271-280. doi:10.1111/j.1654-1103.2007.tb02538.x.

Montesinos, D., Otto, R., and Fernández Palacios, J.M. 2009. Bosques endémicos de Juniperus spp. In Bases ecológicas preliminares para la conservación de los tipos de hábitat de interés comunitario en España. Dir. Gral. de Medio Natural, Ministerio de Medio Ambiente, y Medio Rural y Marino, Madrid, Spain.

-Montesinos, D., Verdú, M., and García-Fayos, P. 2010. Relictual distribution reaches the top: elevation constrains fertility and leaf longevity of the mountain tree Juniperus thurifera. Acta Oecol. 36: 120-125. doi:10.1016/j.actao.2009. 10.010 .

Montesinos, D., García-Fayos, P., and Verdú, M. 2012a. Masting uncoupling: mast seeding does not follow all mast flowering episodes in a dioecious juniper tree. Oikos, 121(11): 1725-1736. doi:10.1111/j.1600-0706.2011.20399.x.

-Montesinos, D., Villar-Salvador, P., García-Fayos, P., and Verdú, M. 2012b. Genders in Juniperus thurifera have different functional responses to variations in nutrient availability. New Phytol. 193(3): 705-712. doi:10.1111/j.1469-8137.2011. 03982.x.

Munger, G.T., Will, R.E., and Borders, B.E. 2003. Effects of competition control and annual nitrogen fertilization on gas exchange of different-aged Pinus taeda. Can. J. For. Res. 33(6): 1076-1083. doi:10.1139/x03-034.

Norusis, M.J. 2002. SPSS 11.0: guide to data analysis. Prentice Hall, Upper Saddle River, New Jersey.

Olano, J.M., Zavala, M.A., and Rozas, V. 2012. Disruption of Juniperus thurifera woodland structure in its northwestern geographical range: potential drivers and limiting factors. Eur. J. For. Res. 131: 563-570. doi:10.1007/s10342-0110531-3.

Olsen, S.R. 1954. Estimation of available phosphorus in soils by extraction with sodium bicarbonate. United States Department of Agriculture, Washington, DC, Circular No. 939.

Petit, R.J., Hampe, A., and Cheddadi, R. 2005. Climate changes and tree phylogeography in the Mediterranean. Taxon, 54(4): 877-885, doi:10.2307/25065474.

Prescott, C.E. 2002. The influence of the forest canopy on nutrient cycling. Tree Physiol. 22(15-16): 1193-200. doi:10.1093/treephys/22.15-16.1193.

Rozas, V., Olano, J.M., DeSoto, L., and Bartolomé, D. 2008. Large-scale structural variation and long-term growth dynamics of Juniperus thurifera trees in a managed woodland in Soria, central Spain. Ann. For. Sci. 65(8): 809-809. doi:10.1051/forest:2008066.

Rubio Delgado, J.L., Sánchez Díaz, J., and Forteza Bonnin, J. 1996. Mapa de suelos de la Comunidad Valenciana. Escala 1: 100000. Hoja n638-637 (AlpuenteLandete). Generalitat Valenciana. Conselleria d'Agricultura, Pesca i Alimentació, Valencia.

Ruiz de la Torre, J., and Ceballos, L. 1971. Árboles y arbustos de la España peninsular. E.T.S.I. de Montes, Madrid.

Saxe, H., Cannell, M.G.R., Johnsen, Ø., Ryan, M.G., and Vourlitis, G. 2001. Tree and forest functioning in response to global warming. New Phytol. 149: 369-400. doi:10.1046/j.1469-8137.2001.00057.x.

Schröter, D., Cramer, W., Leemans, R., Prentice, I.C.C., Araújo, M.B., Arnell, N.W., Bondeau, A., Bugmann, H., Carter, T.R., Gracia, C.A., de la Vega-Leinert, A.C., Erhard, M., Ewert, F., Glendining, M., House, J.I., Kankaanpää, S., Klein, R.J.T., Lavorel, S., Lindner, M., Metzger, M.J., Meyer, J., Mitchell, T.D., Reginster, I., Rounsevell, M., Sabaté, S., Sitch, S., Smith, B., Smith, J., Smith, P., Sykes, M.T., Thonicke, K., Thuiller, W., Tuck, G., Zaehle, S., and Zierl, B. 2005. Ecosystem service supply and vulnerability to global change in Europe. Science, 310(5752): 1333-1337. doi:10.1126/science. 1115233

Terrab, A., Schönswetter, P., Talavera, S., Vela, E., and Stuessy, T.F. 2008. Rangewide phylogeography of Juniperus thurifera L., a presumptive keystone species of western Mediterranean vegetation during cold stages of the Pleistocene. Mol. Phylogenet. Evol. 48(1): 94-102. doi:10.1016/j.ympev.2008.03.018.

Verdú, M., Villar-Salvador, P., and Garcia-Fayos, P. 2004. Gender effects on the post-facilitation performance of two dioecious Juniperus species. Funct. Ecol. 18(1): 87-93. doi:10.1111/j.1365-2435.2004.00816.x.

Walther, G.-R. 2003. Plants in a warmer world. Perspect. Plant Ecol. Evol. Syst. 6(3): 169-185. doi:10.1078/1433-8319-00076.

Zaoui, E.H., Montes, N., Gauquelin, T., Bertaudiere, V., Bradi, W., and Montès, N. 2000. A non-destructive method for estimating above-ground forest biomass in threatened woodlands. For. Ecol. Manage. 130(1-3): 37-46. doi:10.1016/ S0378-1127(99)00188-7. 